\title{
Teaching English using a genre pedagogy to Islamic junior high school students
}

\author{
Aunurrahman ${ }^{1}$, Any Hikmayanti ${ }^{2}$, Yuliana ${ }^{3}$ \\ ${ }^{1}$ Program Studi Pendidikan Bahasa Inggris, Fakultas Pendidikan Bahasa dan Seni, IKIP PGRI \\ Pontianak, Kalimantan Barat, Indonesia \\ 2,3 Madrasah Tsanawiyah Negeri 2 Pontianak, Kalimantan Barat, Indonesia \\ ${ }^{1}$ yarrha@gmail.com (corresponding author) \\ ${ }^{2}$ anyhikmayanticantik@gmail.com \\ ${ }^{3}$ yuliana.arsyad2019@gmail.com \\ Received: November 1, 2019; \\ Accepted: January 29, 2020; \\ Published: March 7, 2020
}

\begin{abstract}
This descriptive qualitative study aims to find out how a genre pedagogy is used to teaching the English language. A class consisted of thirty-six students of a public Islamic junior high school was selected purposefully as participants. The data collection involved participant observation, field notes, and documents, in this case, the students' works. The participant observations were conducted in four meetings. During the observations, this study collected the students' works purposefully. The data analysis used two techniques, namely the thematic analysis to analyze the field notes and functional grammar framework to analyze the students' independent construction texts. The findings of the study reveal that the students could practice daily life texts in pairs and write a daily life text independently, critically, and creatively as they managed to work on their own and to use specific information, expressions, and contexts in their texts as demanded by the government and the $21^{\text {st }}$ century. This could be achieved as the researcher applied genre pedagogy teaching procedures, explicit teaching, and scaffolding to ensure the students could do the work effectively. This study suggests teachers apply genrepedagogy teaching procedures and principles to ensure the students could learn English better.
\end{abstract}

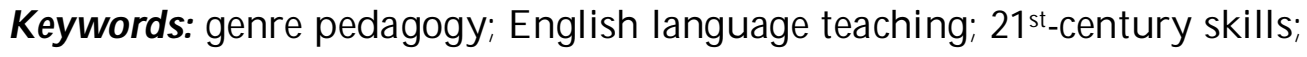
systemic functional linguistics (SFL) 
How to cite this paper (in APA style): Aunurrahman, Hikmayanti, A., \& Yuliana. (2020). Teaching English using a genre pedagogy to Islamic junior high school students. Journal on English as a Foreign Language, 10(1), 1-23. https://doi.org/10.23971/jefl.v10i1.1625

DOI: https: //doi.org/10.23971/jefl.v10i1.1625

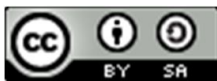

The English language is a language that has been learned worldwide, including in Indonesia. The national curriculum demands students at junior high schools to be able to identify, use, and create simple oral and written interactional and interpersonal texts with their social functions, schematic structures, and linguistic features that are used in daily life (Wachidah et al., 2017b). The

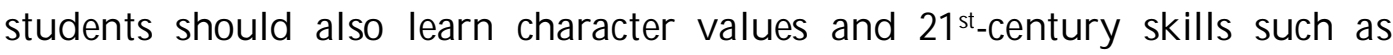
critical thinking (see Ministry of Education and Culture of the Republic of Indonesia, 2018).

To fulfill the demands require a sophisticated and flexible approach for English language teaching. Accordingly, this study would like to propose a genre pedagogy (GP). Specifically, a genre pedagogy that has been developed under systemic functional linguistics (SFL) would be used as a text-based approach to teaching English. The systemic functional linguistics genre-based approach or genre pedagogy will be called as SFL GP hereafter (Botifar, 2018; Cahyono, 2018; Cakrawati, 2018; Emilia \& Hamied, 2015).

SFL GP has been used worldwide, which mainly deals with a written genre. At the level of tertiary education, previous studies by Dickinson (2013), Nagao (20190, and Sabouri et al. (2014) reported that SFL GP could be used to teach academic writing to English as a foreign language (hereafter EFL) students. At the level of secondary education, studies reported that the SFL GP could be used to teach procedural texts to vocational high school students (Istianah, 2011) and to build the senior high school students' character values by using narrative texts (Hardini, 2013). Also, SFL GP had been used to teach writing narrative texts to junior high school students (Zurdianto, 2016), to teach writing recount texts (Hidayat et al., 2018), and to teach speaking skills of descriptive texts to students (Nahid et al., 2018).

These previous studies have shown that SFL GP has been used mainly to teach written genres such as academic writing, procedural texts, and narrative

Journal on English as a Foreign Language, 10(1), 1-23

Copyright @ 2020 by JEFL, p-ISSN 2088-1657; e-ISSN 2502-6615 
texts. It is also had been used to teach speaking skills. However, the descriptive genre used still belongs to a written genre. This means that SFL GP is an appropriate approach that could be used not only to teach writing or speaking skills solely but also to teach English as a whole, which is the focus of the study.

SFL GP lies on three basic principles. The first principle is learning a language is a form of social activity (Emilia \& Hamied, 2015; Martin, 2014). This means that the SFL GP requires a social context. In this study, the social activity or the social context is daily life texts such as giving instruction, invitation and asking permission as demanded by the national curriculum.

The second principle is explicit teaching. Here, teaching a language must be explicit where a teacher provides explanations and resources for the students to learn the social functions, schematic structures, and linguistic features of the genres (Aunurrahman et al., 2017a; Emilia \& Hamied, 2015). Examples of the daily life texts used in this study are provided in Tables 1,2 and 3.

Table 1. A daily life text of instruction

\begin{tabular}{|c|c|c|c|}
\hline Text function & $\begin{array}{l}\text { An example of a daily } \\
\text { life text of instruction }\end{array}$ & $\begin{array}{l}\text { Text organization } \\
\text { (schematic } \\
\text { structure) }\end{array}$ & $\begin{array}{c}\text { Patterns and } \\
\text { expressions } \\
\text { (linguistic features) }\end{array}$ \\
\hline \multirow{4}{*}{$\begin{array}{l}\text { To give } \\
\text { instruction } \\
\text { and respond } \\
\text { to the } \\
\text { instruction }\end{array}$} & $\begin{array}{l}\text { A: Students, do the } \\
\text { writing task on } \\
\text { page } 6 \text {, please! }\end{array}$ & Giving instruction & $\begin{array}{l}\text { Do /Do not + Verb, } \\
\text { please! } \\
\text { Example: } \\
\text { Do your homework }\end{array}$ \\
\hline & & & $\begin{array}{l}\text { Verb + Object, please } \\
\text { Example: } \\
\text { Open the book, } \\
\text { please! }\end{array}$ \\
\hline & $\begin{array}{l}\text { B: All right, } \\
\text { Sir/Ma'am. We will } \\
\text { do the task. }\end{array}$ & $\begin{array}{l}\text { A Response to the } \\
\text { instruction }\end{array}$ & $\begin{array}{l}\text { Alright, Ma'am/Sir. } \\
\text { Sure, Ma'am/Sir. }\end{array}$ \\
\hline & $\begin{array}{l}\text { A: Thank you very } \\
\text { much, my students. }\end{array}$ & $\begin{array}{l}\text { A reply to the } \\
\text { response }\end{array}$ & $\begin{array}{l}\text { Thank you very } \\
\text { much, students. }\end{array}$ \\
\hline
\end{tabular}

(Source: Nurvitasari et al., 2019; Wachidah et al., 2017a)

Tables 1, 2, and 3 show examples of daily life texts with their social functions and linguistic features or expressions learned by the students. These example texts would provide students the explicit knowledge they need to create their own daily texts. The students would also struggle with grammar. Without grammar, the students will not be able to create a meaningful text 
(Alsaawi, 2016; Halliday \& Matthiessen, 2014). In this study, grammar includes using accurate spelling punctuation, capitalization, lexical choices, and cohesive devices that are useful to build a meaningful text (Alsaawi, 2016; Aunurrahman et al., 2017a).

Table 2. A daily life text of invitation

\begin{tabular}{|c|c|c|c|}
\hline Text function & $\begin{array}{l}\text { An example of a daily } \\
\text { life text of invitation }\end{array}$ & $\begin{array}{c}\text { Text organization } \\
\text { (schematic } \\
\text { structure) }\end{array}$ & $\begin{array}{c}\text { Patterns and } \\
\text { expressions (linguistic } \\
\text { features) }\end{array}$ \\
\hline \multirow{3}{*}{$\begin{array}{l}\text { To invite } \\
\text { someone to } \\
\text { go } \\
\text { somewhere } \\
\text { or do } \\
\text { something }\end{array}$} & $\begin{array}{l}\text { A: B, would you go to } \\
\text { my house } \\
\text { tomorrow? }\end{array}$ & To invite someone & $\begin{array}{l}\text { Would you come ....? } \\
\text { Let us go to .... }\end{array}$ \\
\hline & $\begin{array}{l}\text { B: Sure, I would love } \\
\text { to go to your house } \\
\text { tomorrow }\end{array}$ & $\begin{array}{l}\text { A response to the } \\
\text { invitation }\end{array}$ & $\begin{array}{l}\text { Sure, I would love to } \\
\text {... } \\
\text { Unfortunately, I could } \\
\text { not }\end{array}$ \\
\hline & $\begin{array}{l}\text { A: Thank you very } \\
\text { much, B. I will see } \\
\text { you tomorrow } \\
\text { then. }\end{array}$ & $\begin{array}{l}\text { A reply to the } \\
\text { response }\end{array}$ & $\begin{array}{l}\text { Great, I will see you } \\
\text { tomorrow then } \\
\text { Well, that is all right. } \\
\text { Maybe next time. }\end{array}$ \\
\hline
\end{tabular}

(Source: Nurvitasari et al., 2019; Wachidah et al., 2017a)

The third principle is guidance. Teaching is more than just transferring the knowledge above to the students. It is also about providing proper guidance or also known as scaffolding that would help the students to be independent in learning especially in constructing their own texts individually (Kuiper et al., 2017; Kusumaningrum, 2015; Martin \& Rose, 2005; Nugraha, 2013).

In brief, the three key principles of SFL GP have an important contribution to the successful teaching of EFL where a teacher should know the context or the purpose of the teaching, in this case, to teach daily life texts. A teacher should also provide explicit instruction and information by using interesting media such as pictures and model texts to help the students to learn EFL (see Tables 1, 2 and 3). Not only that, a teacher should provide guidance whenever the students need it before they could work independently.

Furthermore, SFL GP has its own teaching procedures that are commonly used in Indonesia. The teaching procedures used are "building knowledge of the field, modeling, joint construction, and independent construction stages" (Aunurrahman et al., 2017a, p. 29; Aunurrahman et al., 
2017b; Emilia, 2012) with a little adaptation of Reading to Learn teaching strategy where the students used a rewriting strategy (Martin \& Rose, 2005; Whittaker, 2018). In this study, the rewriting strategy was used by changing a context of a text such as changing the names, expressions used and or changing the activity in the text adapted from Martin \& Rose (2005), Rose (2005), and Whittaker (2018).

Table 3. A daily life text of permission

\begin{tabular}{|c|c|c|c|}
\hline Text function & $\begin{array}{l}\text { An example of a daily } \\
\text { life text of invitation }\end{array}$ & $\begin{array}{c}\text { Text organization } \\
\text { (schematic } \\
\text { structure) }\end{array}$ & $\begin{array}{c}\text { Patterns and } \\
\text { expressions (linguistic } \\
\text { features) }\end{array}$ \\
\hline $\begin{array}{l}\text { To ask and } \\
\text { give }\end{array}$ & $\begin{array}{l}\text { A: Ma'am, may I go to } \\
\text { the toilet? }\end{array}$ & To ask permission & May I go ....? \\
\hline $\begin{array}{l}\text { permission } \\
\text { to go } \\
\text { somewhere }\end{array}$ & $\begin{array}{l}\text { B: Of course, you may } \\
\text { go to the toilet, A }\end{array}$ & $\begin{array}{l}\text { To give } \\
\text { permission }\end{array}$ & $\begin{array}{l}\text { Sure, you may ... } \\
\text { I am sorry but you } \\
\text { may not ... }\end{array}$ \\
\hline $\begin{array}{l}\text { or to do } \\
\text { something }\end{array}$ & $\begin{array}{l}\text { A: Thank you very } \\
\text { much, Ma'am. }\end{array}$ & $\begin{array}{l}\text { A reply to the } \\
\text { response }\end{array}$ & $\begin{array}{l}\text { Thank you very much, } \\
\text { Ma'am } \\
\text { That is fine. I will } \\
\text { contact others .... }\end{array}$ \\
\hline
\end{tabular}

(Source: Nurvitasari et al., 2019; Wachidah et al., 2017a)

Accordingly, this study aims to find out how SFL GP is used to teaching English to Islamic junior high school students in Pontianak, West Kalimantan, Indonesia. To be noted, the difference with the previous studies is that this study would like to focus on spoken texts or genres that are used in daily life, such as giving instruction, invitation, and permission. Another difference is that this study would apply SFL GP with a little adaption of a Reading to Learn teaching strategy to students of a public Islamic junior high school in Pontianak, West Kalimantan, Indonesia where little research on SFL GP in this context had been conducted. Hopefully, this study could provide insight for EFL teachers and lecturers around the world that SFL GP is a flexible and customizable approach that can help them to teach EFL.

\section{METHOD}

\section{Research Design}

This was a descriptive qualitative study aiming to find out how SFL GP as a text-based approach used to teaching the English language. The participants were thirty-six students of an eighth-grade class from a public 
Islamic junior high school in Pontianak. This study used purposeful sampling that is common to be used in a qualitative study to select participants (Benoot et al., 2016; Palinkas et al., 2015). Here, a discussion was conducted by the main researcher with the co-researchers to decide a class to be involved in this study. As a result, the researchers decided to choose a class without specific characteristics or weaknesses or strengths the class had. As long as the class could provide rich information, this study could be conducted (Gentles et al., 2015).

\section{Data Collection}

This study used multiple qualitative-based instruments to achieve the aim of the study. The first instrument was participant observations that recorded the teaching and learning activities in the classroom. The main or the first researcher acted as an English teacher. The co-researchers or the second and third researchers acted as collaborators.

The function of the collaborators is to provide reflections and feedback to ensure better performance of the teaching and learning activities and also to reduce the bias of the results of the participant observation (Fraenkel et al., 2011). The field notes of the observation were written by the main researcher after discussions with the co-researchers. The discussions took place after the class ended to provide feedback and reflections. The participant observations were conducted in 4 meetings in two weeks.

The second instrument was document. In this study, the researchers collected the students' works that had been done during the teaching and learning activities. The students' works contain important data that would describe the results of the teaching and learning activities under SFL GP adapted from Bowen (2009). To be noted, the students' works were done in a worksheet provided by the researchers.

Due to limited space, only one students' work that was written by Nara, Dede, Zaza, Desi, Amir, Dodo, and Dani (in pseudonyms) in the joint construction stage and three students' works in the independent construction stage would be presented. The students' names are Nara who represented the high achiever, Zaza who represented the mid achiever, and Dede who represented the low achiever (in pseudonyms). This assignation was based on the researcher and collaborator's classroom observations and the students' works.

Journal on English as a Foreign Language, 10(1), 1-23

Copyright @ 2020 by JEFL, p-ISSN 2088-1657; e-ISSN 2502-6615 


\section{Data Analysis}

There are two kinds of qualitative data analysis used. The first technique of data analysis is thematic analysis to analyze textual data from the observation field notes. The thematic analysis used an inductive approach to find important themes that frequently occur in field notes (Maguire \& Delahunt, 2017; Thomas, 2006). The procedure of the thematic analysis began with finding important themes in the field notes. The themes were mainly related to the teaching and learning activities of SFL GP such as the applications of the SFL GP teaching procedures that consist of six stages and three key teaching principles of SFL GP. The researchers then used the above textual data in the finding section as descriptions of how the SFL GP is used in the teaching of EFL.

Certainly, descriptions of the activities would not be enough. Accordingly, evidence of the students' works was presented in this study along with the descriptions of SFL GP activities from the field notes in a narrative form in the following section. Using multiple evidence would help this study to build a convergent validity and to reduce bias. This is also called a methodological triangulation (Fusch et al., 2018).

Here, the students' works were analyzed by using the FG framework. The analyzed students' works were the students' texts from the independent construction stage. Meanwhile, the students' works from the building knowledge of the field and joint construction stages would only be presented as evidence to support the descriptions of the observation field notes as the students only required to choose the right responses and to construct certain expressions (see Table 4).

The text analysis of the students' works began with the main researcher determined the schematic structure of the students' texts (see Tables 1, 2, and 3). Then, the sentence patterns and expressions used in the texts were categorized into three aspects of SFL namely the textual metafunction - organization of information that builds ideas, ideational metafunction (logical metafunction logical relationship of ideas and experiential metafunction - ideas), and interpersonal metafunction- how a language is used to communicate ideas (Banks, 2002; Martin, 2014; Oliveira, 2015). The main researcher then discussed the results of the data analysis with the co-researchers to provide reflections and feedback. This session was conducted to ensure that this study could provide valid textual data of the students' texts. The valid data would be used

Journal on English as a Foreign Language, 10(1), 1-23

Copyright @ 2020 by JEFL, p-ISSN 2088-1657; e-ISSN 2502-6615 
to strengthen the descriptions of the SFL GP activities that would be elaborated in the following section.

\section{FINDINGS}

This section presents the descriptions of the SFL GP activities that show how SFL GP teaching principles and procedures were used in the teaching of EFL. The textual data of the students' works were presented to strengthen the descriptions.

The presentation would begin with the stages of SFL GP teaching procedures. The first stage is building knowledge of the field stage. This stage was conducted in the first meeting where the researcher who acted as the teacher introduced the topic and the daily life texts that would be learned by the students. The topic is daily life which is limited to daily life at schools and at home. Then, the teacher showed pictures to see the students' prior knowledge of daily life. This practice is also used to build students' character values and $21^{\text {st }}$-century skills such as critical thinking. A sample of a building knowledge activity completed by Nara is shown in Table 4 .

Table 4. A sample of building knowledge of the field activity

Text of instruction Purposes of the activity

Circle an appropriate answer!

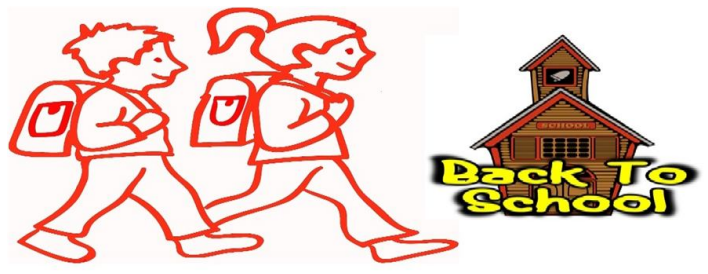

(Images are taken from Clker-Free-Vector-

Images, 2012; Rohmann, 2015)

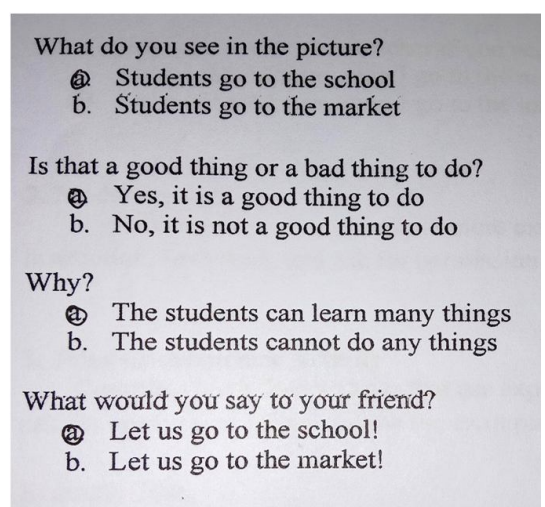

Seeing the students' prior

knowledge toward the picture

Building students' character value know what is right and wrong

Building students' critical thinking element - providing a logical reason

Directing the students' attention to a daily life text - to give the invitation 
Table 4 shows a sample of building knowledge of the field activity completed by Nara. Here, Nara simply chose the right answers that are in accordance with the picture. This stage allowed the researchers to see the students' prior knowledge of the topic that was learned by the students. Then, in the right column, there are purposes of the activity. Here, the purposes of the activity could reflect the activity of character building (moral reasoning) and a critical thinking skill (logical reasoning) as demanded by the government in this $21^{\text {st }}$ century (Ministry of Education and Culture of the Republic of Indonesia, 2018). It is also a form of an introduction to the daily life texts that the students would learn further in the modeling stage.

In the building knowledge of the field activity, the students did have difficulty following the instruction provided by the main researcher where they were required to circle their responses. This could happen as the instruction provided by the main researcher was different from the instructions usually provided by the English teacher, Ms. Any Hikmayanti, the co-researcher of this research. As a result, the main researcher with the help of the co-researcher explained further the instruction explicitly and provided the necessary guidance to help the students to complete the task provided. Explicit instruction and guidance are the basic principles of SFL GP (Aunurrahman et al., 2017a; Emilia \& Hamied, 2015; Hyland, 2007) that were used throughout the teaching procedures. This would lead the students to be independent in learning as they became accustomed to the tasks given to them in the worksheet.

The second stage is the modeling stage. The stage is used to introduce further the schematic structures and linguistic features of daily texts of giving instruction, invitation, and asking. To make the lesson interesting, the researcher used videos that were taken from channels from a popular videosharing website (e.g. https:/youtu.be JFnQ0gxef2A that shows conversations of daily texts of invitation). This is a form of digital literacy to help the students in learning the English language (Chan et al., 2017; McGuinness \& Fulton, 2019). The main researcher provided and played videos in an offline mode to avoid unnecessary technical and network issues.

The videos used contain interesting animated figures with music that introduce social purposes, patterns, expressions, and examples of the daily life texts in different contexts. The videos used could build the students' interest to understand and learn further the learning materials as they watched the videos and listened to the background music from the videos seriously and 
comfortably (Bokiev et al., 2018; Brecht, 2012). At certain points of time, the main researcher paused the videos and provided an explanation to help the students to understand better the learning materials.

The main researcher also asked the students to read aloud the examples of expressions and dialogues on the videos. After watching the videos, the researcher asked the students to practice in pairs with more examples of daily life texts provided in the textbook. It was shown by Nurvitasari et al. (2019) for the examples of the practices. The researcher and the co-researcher monitored the pair works and provided guidance such as showing how to pronounce a word that the students did not know how to pronounce it. At the end of the meeting, the researcher asked the students to find out any difficulties they had during the teaching and learning activities. The students did not mention anything about difficulties. But, it does not mean that the students had no difficulties earlier.

In the second meeting, the students entered the joint construction stage. The co-researcher, Ms. Any Hikmayanti began the class by giving questions about what they had learned in the first meeting to help recall the students' knowledge of the daily life texts. Afterward, the main researcher instructed the students to work on a task in the worksheet in groups where the students completed three daily life texts of giving instruction, invitation and asking permission. The students were assigned to groups by using random numbers to avoid the students to work with their very close friends (Emilia, 2012).

Before working on the task, the main researcher explicitly provided an example of how to work on the task. Also, the main researcher monitored and guided the students while working in a group. This stage was also used to build the students' sense of collaboration and communication where the students worked in groups and learned to work and communicate as a team (see Aunurrahman et al., 2017a; Ministry of Education and Culture of the Republic of Indonesia, 2018). Even though the students already provided guidance, the main researcher still identified minor mistakes after the students completed their first drafts. A sample of the students' work in a group written by Nara, Dede, Desi, Zaza, Amir, Dodo, and Dani is provided in Table 5.

Table 5 shows that the students could complete the daily life texts provided by the main researcher. The table also shows that the students' works had minor grammatical issues. In the third meeting, the researcher provided feedback and instructed the students to revise their writings. The words in

Journal on English as a Foreign Language, 10(1), 1-23

Copyright @ 2020 by JEFL, p-ISSN 2088-1657; e-ISSN 2502-6615 
square brackets are examples of the feedback given to the students before the students entered the independent construction stage. The students then revised their answers. To be noted, even though the students worked in groups, they still had to write their answers on their worksheets individually. This would help them to remember better what they had learned and composed. The students' final draft is in Figure 1.

Table 5. The students' work in the joint construction stage

\begin{tabular}{|c|c|c|}
\hline \multicolumn{2}{|c|}{$\begin{array}{l}\text { Daily life texts written by Nara, Dede, Desi, Zaza, Amir, } \\
\text { Dodo, and Dani }\end{array}$} & $\begin{array}{c}\text { Schematic structure of } \\
\text { the text }\end{array}$ \\
\hline \multicolumn{3}{|c|}{ Text 1} \\
\hline Teacher & ease read th & To \\
\hline Heri & Yes, Ma'am. I will reading [read] the text loudly. & \\
\hline $\begin{array}{l}\text { Teacher } \\
\text { Text } 2\end{array}$ & Thank you, Heri. & A reply to the respo \\
\hline Father & $\begin{array}{l}\text { I want to visit a bookstore, Don. Would, } \\
\text { to the bookstore with me? }\end{array}$ & To g \\
\hline Don & $\begin{array}{l}\text { I would love to go to the bookstore with you, } \\
\text { father. But, I must do my homework. }\end{array}$ & A response \\
\hline Father & $\begin{array}{l}\text { : Great, Don. Do your homework first then we } \\
\text { will go to the bookstore together. }\end{array}$ & A reply to the response \\
\hline \multicolumn{3}{|l|}{ Text 3} \\
\hline Heri & let, mam [Ma'am]? & \\
\hline Teacher & $\begin{array}{l}\text {, you may go to the toilet. But do not } \\
\text { g or you will be punished. }\end{array}$ & $\begin{array}{l}\text { A re } \\
\text { perl }\end{array}$ \\
\hline Heri & : Thank you very much, Ma'am. & to the response \\
\hline Teacher & : You are welcome, Heri. & \\
\hline \multicolumn{3}{|l|}{ Notes: } \\
\hline \multicolumn{3}{|c|}{$\begin{array}{l}\text { a. The underlined word(s) and sentence(s) are the students' answers. } \\
\text { b. Word(s) or expressions in square brackets [] are feedback provided by the main } \\
\text { researcher }\end{array}$} \\
\hline \multicolumn{3}{|c|}{$\begin{array}{l}\text { Figure } 1 \text { shows the final draft of the students' work after they had been } \\
\text { given feedback by the main researcher. Here, the students simply struck } \\
\text { through their mistakes and added the correct versions of the words. Knowing } \\
\text { the mistakes they had made would help them to be accurate and pay attention } \\
\text { to details as constructing a meaningful text depends on the use of grammar in } \\
\text { the text. This form of accuracy is also an aspect of critical thinking or known as } \\
\text { an intellectual standard (Elder \& Paul, 2013). }\end{array}$} \\
\hline
\end{tabular}

Journal on English as a Foreign Language, 10(1), 1-23

Copyright @ 2020 by JEFL, p-ISSN 2088-1657; e-ISSN 2502-6615 


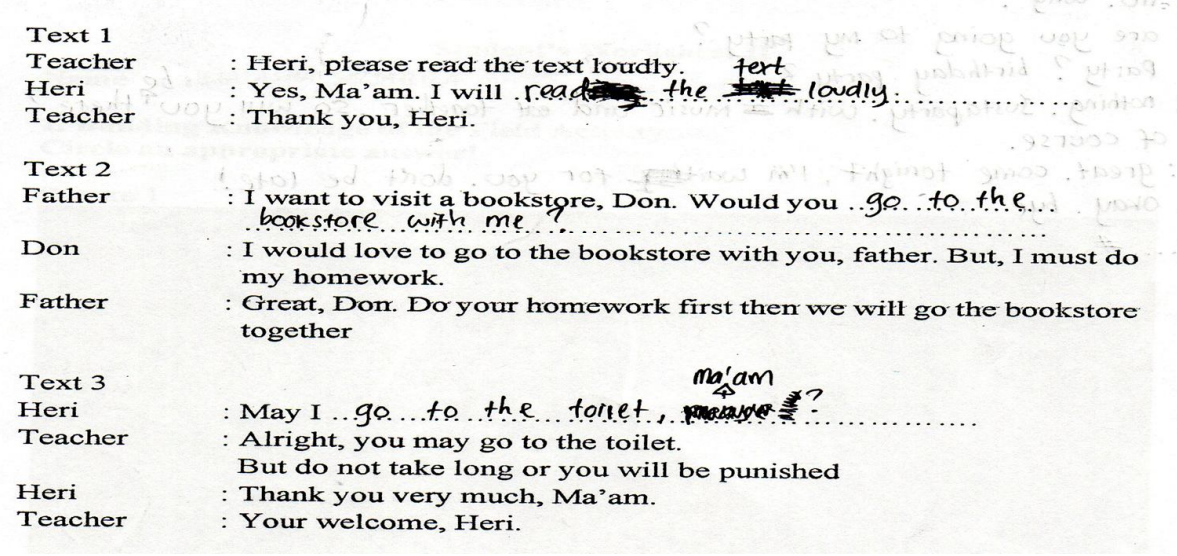

Figure 1. The students' final draft in the joint construction stage

Still in the third meeting, after revising the joint construction texts, the students entered the independent construction stage. Here, the main researcher instructed the students to rewrite only one daily life text. The students were allowed to choose what daily text they would rewrite. The students could simply rewrite a text from the worksheet or the textbook they had. The key to this activity is to help them to be independent in writing a text. The stage began with the students had to build their own knowledge of what to be written in their worksheets. The modeling stage was skipped as the students already accustomed to the pattern and expressions used in daily life texts. Nevertheless, the main researcher still provided guidance and correction to ensure they could write a meaningful text.

The main researcher also informed the students that they needed to change the context of the text such as changing the names, expressions used and or changing the activity in the text (adapted from Martin \& Rose, 2005; Rose, 2005). In addition, after completing the first drafts, the students practiced their own dialogues with their peers in pairs. The students did find difficult words to be pronounced and asked the researcher the correct pronunciation.

Due to limited space, only the texts written by Nara (high achiever), Zaza (mid achiever), and Dede (low achiever) are presented in Table 6. It shows that the students were able to construct a text independently even though they mainly rewrote the texts from the joint construction stages provided in the worksheet (see Table 5). The researcher identified grammatical mistakes and provided feedback in the fourth meeting or the last meeting to the students 
before they submitted the final drafts to ensure the students learned to provide accurate and meaningful text. The texts in Table 6 were analyzed by using the FG framework to see how the students had used their capacities of the English language.

Table 6. The students' works in the independent construction stage

\begin{tabular}{|c|c|c|}
\hline \multicolumn{2}{|c|}{ Daily life texts written by Nara, Zaza, Dede } & Schematic structure \\
\hline Text 1 & By Nara & \\
\hline Nara & : Excuse me, may i [I] go to the toilet, Ma'am? & To ask permission* \\
\hline Teacher & : Alright, you may go to the toilet. & A response \\
\hline Nara & : Thank you very much, Ma'am. & A reply to the response \\
\hline Text 2 & By Zaza & \\
\hline Teacher & : Ezi, please read the assignment. & To give instruction* \\
\hline Ezi & : Yes, Ma'am. I will read the assignment. & A response \\
\hline Teacher & : Thank you, Ezi. & A reply to the response \\
\hline Text 3 & By Dede & \\
\hline Andi & : May I go to the canteen? Sir [canteen, Sir?] & To ask permission* \\
\hline Ardi & : All right, you may go to the canteen. & A response \\
\hline Andi & : Thank you, Ma'am. [Sir] & A reply to the response \\
\hline Ardi & : Your [You are] welcome & \\
\hline
\end{tabular}

a. The underlined word(s) and sentence(s) are the students' answers.

b. Word(s) or expressions in square brackets [] are feedback provided by the main researcher

c. * indicates the macroTheme of the text

The first two aspects that would be presented are the textual and logical metafunctions. The texts written by Nara and Dede (see Table 6) mainly use a theme reiteration pattern that is signaled by a topical Theme " $\mathrm{I}$ ", which is in the form of a first-person pronoun and preceded by an interpersonal Theme "may", reiterated by another topical Theme in the form of third-person personal pronoun "you" as the texts are in the form of dialogue that shows an interaction between two speakers. Another example is using the name "Ezi" (in the text written by Zaza) that is reiterated by a first-person pronoun "I."

In relation to logical metafunction, the utilization of the first-person and third-person pronouns in the texts are called references, which are a form of cohesive device that allows the listener to grasp the identity of the speaker (Emilia, 2014; Halliday \& Matthiessen, 2014). Without the references, the conversation would not happen due to a confusion of the participants referred to in a text. 
A theme reiteration pattern is a common pattern of spoken language that allows the speaker to communicate his or her message in a dialogue or a conversation in a consistent manner (Emilia, 2014; Gunawan \& Aziza, 2017), in this case, to ask permission and to give instruction as indicated by the macroThemes of the texts (see Table 6). MacroTheme is the main idea or the main focus of a text (Emilia, 2014).

The last two aspects that would be presented are the experiential and interpersonal metafunctions. Mainly, the texts use material processes such as "go", and "read" that signal physical activity (Emilia, 2014; Halliday \& Matthiessen, 2014). In their contexts, the material processes are preceded by a deontic modality "may" (in texts written by Nara and Dede) that signals asking permission and a form of politeness in communicating a message.

Nara in her text also added "Excuse me" before the modality to get the attention of the listener (Morley, 2000). Another example is in the text written by Zaza that uses name "Ezi" to get the attention of the listener followed by "please", which is a form of circumstance that signals a polite instruction (Morley, 2000) and proceeded by a deontic modality "will" that signals an attempt to do the instruction.

At the end of the three texts, the writers use "Thank you" to signal gratitude. The expression of gratitude is followed by vocative adjuncts such as "Sir" and "Ma'am" which are used to address the listeners respectfully and to get attention from them (Emilia, 2014; Morley, 2000). Unfortunately, Dede has used an irrelevant vocative adjunct earlier where, at the beginning of the dialogue, Dede uses "Sir" but, at the end of the dialogue, Dede uses "Ma'am." This could lead to confusion in understanding the text.

Other forms of circumstance are used to signal locations. The samples (see Table 6) are "to the toilet" (in Nara's text) and to the canteen (in Dede's text), to signal agreement such as "yes" (in Zaza's text) and "alright" (in Nara and Dede's texts). These circumstances provide specific and clear information (Elder \& Paul, 2013).

Apparently, the students also paid attention to the contexts where they had changed the contexts of the examples provided in the worksheet (see Table 5 ) to their own contexts such as Nara who uses the expression "Excuse me" at the beginning of the text to get attention from the teacher. Zaza and Dede also made a change to the activities where the examples in Table 5 use "read the text

Journal on English as a Foreign Language, 10(1), 1-23

Copyright @ 2020 by JEFL, p-ISSN 2088-1657; e-ISSN 2502-6615 
loudly" had been changed by Zaza into "read the assignment" and "go to the toilet" had been changed by Dede to "go to the canteen." This could show a sense of creativity and independence that had been achieved by the students in the independent construction stage despite grammatical mistakes that were identified earlier.

In brief, the findings of the study reveal that SFL GP teaching procedures and principles with a little adaptation of a Reading to Learn strategy, namely a rewriting strategy are the key elements to answer how SFL GP is used in the teaching of the English language. The discussions between the main researcher and the co-researchers in search of reflections and feedback also helped this study to cope with the issues during the teaching and learning activities. The students' works as shown in Tables 5 and 6 reveal that the students could show their capacities in the English language even though minor grammatical mistakes were identified. Apparently, the students also had shown their capacities of character value (moral reasoning) and $21^{\text {st }}$-century skill (critical thinking - logical reasoning) as indicated in Table 4, which are also reflected in the students' joint construction and independent construction texts (see the analysis of the students' texts in Figure 1 and Table 6).

\section{DISCUSSION}

The findings from the participant observations and students' documents have shown that SFL GP could be used to teaching the English language to Islamic junior high school students. The participant observations field notes show that teaching procedures of SFL GP with a little adaptation of a Reading to Learn teaching strategy (Martin \& Rose, 2005; Rose, 2005) are not the only aspect that needs to be paid attention. A teacher should also incorporate the three principles of SFL GP as discussed in the following paragraphs.

Learning a language is a form of social activity. That is why, particular texts with their social purposes, schematic structures, and linguistic features were used in this study and documented as the students' works (see Table 6). To achieve the knowledge and skills required to construct the particular texts, in this case, daily life texts, a teacher should apply explicit teaching and instructions where everything that students needed to know and learn must be explicitly informed to them (Emilia, 2012; Frankel, 2013; Liu, 2018; SchallLeckrone, 2017; Vygotsky, 1978). Without clear information and instructions will make the students confused in following the teaching and learning activities.

Journal on English as a Foreign Language, 10(1), 1-23

Copyright @ 2020 by JEFL, p-ISSN 2088-1657; e-ISSN 2502-6615 
Not only that, but a teacher should also provide scaffolding or guidance and feedback to ensure that they could work the tasks provided and as a preparation for the students to work independently (Emilia, 2012; Negretti \& McGrath, 2018; Smit et al., 2016; Vygotsky, 1978). Here, the guidance and feedback serve as ways that helped the students to construct independent construction texts independently and creatively as shown in Table 6.

As a result, the students could write their independent construction texts even though minor mistakes were identified. The students could use the schematic structure of the daily life texts with their linguistic features properly as they learned to use them in their own contexts (see Table 6). Moreover, the teaching procedures and the texts that had been analyzed could realize a form of character education and $21^{\text {st }}$-century skills such as critical thinking where the students learned to provide logical and moral reasoning when they were answering questions in the building knowledge of the field (see Table 4). Then, the students learned to collaborate as they worked as a team in the joint construction stage.

Also, the students learned to use specific and clear information such as circumstances and other linguistic features properly and grammatically correct in the independent texts (see Table 6) that could signal the aspects of critical thinking (Elder \& Paul, 2013). This leads to a point that SFL GP could adapt to the needs of the $21^{\text {st }}$ century as the flexibility that has been offered by the principles of SFL GP.

These findings are in line with previous studies that reported SFL GP could be used to teach the students' skills in writing procedural types (Istianah, 2011), in writing narrative texts (Zurdianto, 2016) and recount texts (Hidayat et al., 2018), and to build the senior high school students' character values by using narrative texts (Hardini, 2013). Unlike the previous studies, this study not only used SFL GP teaching procedures and principles but also added a rewriting strategy, a form of a Reading to Learn teaching strategy or procedure, to help the students in constructing their texts. The rewriting strategy allows the students to change the context, names, and activities of their texts by adapting from the joint construction texts provided in the worksheet adapted from Martin and Rose (2005), Rose (2005), and Whittaker (2018).

Unfortunately, this study also has a limitation. This study did not measure or analyze the students' skills in speaking as had been done by Nahid et al. (2018) who reported that SFL GP could be used to teach the students' skills

Journal on English as a Foreign Language, 10(1), 1-23

Copyright @ 2020 by JEFL, p-ISSN 2088-1657; e-ISSN 2502-6615 
in speaking descriptive texts. Nevertheless, this study did use speaking skills to help the students to practice their capacities in using the schematic structures and linguistic features of the daily texts that the students had learned before and after they constructed their texts independently. At certain points of time, the students learned to pronounce certain words or expressions that they did not know how to pronounce it.

\section{CONCLUSION}

The findings of this study reveal that SFL GP provides flexible basic principles and teaching procedures that could cope with the needs of the $21^{\text {st }}$ century. This allows the study to utilize SFL GP to teach what the students' needs, which are not only about the schematic structures and linguistic features of the daily texts but also how the students learn to be critical, specific, accurate, and meaningful in providing reasons and information and constructing daily life texts. The students also learned to collaborate as they worked as a team before they are able to work independently and creatively. Certainly, this could not be achieved without an important role of a teacher that is not only to teach but also to guide the students to reach independence. Nevertheless, this study also has a limitation. The limitation of this study is that this study only utilized SFL GP to a class that consisted of 36 students and only focused on writing as the students learned better through writing. This means that this study is not intended for a generalization. Future studies could be conducted in a different context and to emphasize different skills such as listening and speaking, which are still limited.

\section{ACKNOWLEDGEMENT}

This article is a collaborative work of the main researcher, Aunurrahman, from IKIP PGRI Pontianak with the co-researchers, Any Hikmayanti and Yuliana, from MTs Negeri 2 Pontianak. The collaborative work is sponsored by The Ministry of Research and Higher Education under the program of lecturer assignment at schools or known as Penugasan Dosen di Sekolah.

\section{REFERENCES}

Alsaawi, A. (2016). Written discourse analysis and its application in English language teaching. Arab World English Journal (AWEJ), 7(2), 244-254. https://doi.org/10.2139/ssrn.2814821

Aunurrahman, Hamied, F. A., \& Emilia, E. (2017a). A joint construction practice in an academic writing course in an Indonesian university context. Celt

Journal on English as a Foreign Language, 10(1), 1-23

Copyright @ 2020 by JEFL, p-ISSN 2088-1657; e-ISSN 2502-6615 
(A Journal of Culture, English Language Teaching E Literature), 17(1), 27-44. https://doi.org/10.24167/celt.v17i1.1137

Aunurrahman, Hamied, F., \& Emilia, E. (2017b). Realizing a good education in an Indonesian university context. In A. G. Abdullah, I. Hamidah, S. Aisyah, A. A. Danuwijaya, G. Yuliani, \& H. S. H. Munawaroh (Eds.), Ideas for 21st Century Education: Proceedings of the Asian Education Symposium (AES 2016) (pp. 297-300). London: Routledge. https://doi.org/10.1201/9781315166575

Banks, D. (2002). Systemic functional linguistics as a model for text analysis. ASp. La Revue Du GERAS, 10(35-36), 23-34. https://doi.org/10.4000/asp.1584

Benoot, C., Hannes, K., \& Bilsen, J. (2016). The use of purposeful sampling in a qualitative evidence synthesis: A worked example on sexual adjustment to a cancer trajectory. BMC Medical Research Methodology, 16(1), 21. https://doi.org/10.1186/s12874-016-0114-6

Bokiev, D., Bokiev, U., Aralas, D., Ismail, L., \& Othman, M. (2018). Utilizing music and songs to promote student engagement in ESL classrooms. International Journal of Academic Research in Business and Social Sciences, 8(12), 314-332. https: //doi.org/10.6007 /JARBSS $/$ 8-i12 5015

Botifar, M. (2018). Teaching writing in Indonesian language classes with a genre-based approach (GBA): Between hope and reality (an analysis of lesson plans in the Curriculum 2013 classroom). KnE Social Sciences, 3(9), 395-410. https://doi.org/10.18502/kss.v3i9.2701

Bowen, G. A. (2009). Document analysis as a qualitative research method. Qualitative Research Journal, 9(2), 27-40. https://doi.org/10.3316/QRJ0902027

Brecht, H. D. (2012). Learning from online video lectures. Journal of Information Technology Education: Innovations in Practice, 11, 227-250. Retrieved from https: //eric.ed.gov /:id=EJ990981

Cahyono, S. P. (2018). Teaching L2 writing through the use of systemic functional linguistics (SFL). Indonesian JELT, 13(1), 53-72. https://doi.org/10.25170/ijelt.v13i1.1179

Cakrawati, L. M. (2018). Recount text in SFL perspective: Pedagogical implication based on student's writing analysis. Register Journal, 11(2), 210-227. https://doi.org/10.18326/rgt.v11i2.210-227

Chan, B. S. K., Churchill, D., \& Chiu, T. K. F. (2017). Digital literacy learning in higher education through digital storytelling approach. Journal of International Education Research (JIER), 13(1), 1-16. https://doi.org/10.19030/jier.v13i1.9907 
Clker-Free-Vector-Images. (2012). Free image on pixabay-back to school. München: Pixabay. Retrieved from https://pixabay.com/vectors/back-toschool-school-back-student-40596/

Dickinson, P. (2013). A genre-based approach to preparing for IELTS and TOEFL essay writing tasks. 新潟国際情報大学情報文化学部紀要, 16, 1-9. Retrieved from http://cc.nuis.ac.jp/library/files/kiyou/rol16/16_dickinson_1.pdf

Elder, L., \& Paul, R. (2013). Critical thinking: Intellectual standards essential to reasoning well within every domain of human thought. Journal of Developmental Education, 36(3), 34-35. Retrieved from https:/files.eric.ed.gov/fulltext/EJ1067273.pdf

Emilia, E. (2012). Pendekatan genre-based dalam pengajaran bahasa Inggris: Petunjuk untuk guru [Genre-based approach in English language teaching: Instructions for teachers] (2nd ed.). Bandung: Rizqi Press.

Emilia, E. (2014). Introducing functional grammar. Bandung: Pustaka Jaya

Emilia, E., \& Hamied, F. A. (2015). Systemic functional linguistic genre pedagogy (SFL GP) in a tertiary EFL writing context in Indonesia. TEFLIN Journal, 26(2), 155-182. https://doi.org/10.15639/eflinjournal.v26i2/155-182

Fraenkel, J. R., Wallen, N. E., \& Hyun, H. H. (2011). How to design and evaluate research in education ( $8^{\text {th }}$ ed.). New York: McGraw-Hill Humanities/Social Sciences/Languages.

Frankel, K. K. (2013). Revisiting the role of explicit genre instruction in the classroom. Journal of Education, 193(1), 17-30. https://doi.org/10.1177/002205741319300103

Fusch, P., Fusch, G., \& Ness, L. (2018). Denzin's paradigm shift: Revisiting triangulation in qualitative research. Journal of Social Change, 10(1), 19-32.

Gentles, S., Charles, C., Ploeg, J., \& McKibbon, K. A. (2015). Sampling in qualitative research: Insights from an overview of the methods literature. The Qualitative Report, 20(11), 1772-1789. Retrieved from https://nsuworks.nova.edu/tqr/Nol20/iss11/5

Gunawan, W., \& Aziza, F. (2017). Theme and thematic progression of undergraduate thesis: Investigating meaning-making in academic writing. Indonesian Journal of Applied Linguistics, 7(2), 413-424. https://doi.org/10.17509/ijal.v7i2.8350

Halliday, M. A. K., \& Matthiessen, C. M. I. M. (2014). Halliday's introduction to functional grammar ( $4^{\text {th }}$ ed.). Oxfordshire: Routledge.

Hardini, S. R. (2013). Developing character values in the teaching of narrative texts using genre-based approach: A case study at a senior high school in Bandung 
(Unpublished postgraduate thesis). Universitas Pendidikan Indonesia, Bandung, Indonesia. Retrieved from http://repository.upi.edu/2181

Hidayat, R. W., Setyowati, L., \& Mabaroh, B. (2018). Genre-based approach for writing recount text at MTs "Darul Ulum" Karang Pandan, Pasuruan. Jurnal Bahasa Lingua Scientia, 10(1), 61-80. https://doi.org/10.21274/1s.2018.10.1.61-80

Hyland, K. (2007). Genre pedagogy: Language, literacy and L2 writing instruction. Journal of Second Language Writing, 16(3), 148-164. https://doi.org/10.1016/j.jslw.2007.07.005

Istianah, T. (2011). The use of genre-based approach in teaching writing procedural texts to improve students' writing skill to the eleventh grade of SMK N 1 Slawi (in the academic year of 2010/2011) (Unpublished thesis). Universitas Negeri Semarang, Semarang, Indonesia. Retrieved from http://ib.unnes.ac.id/6377/1/7514.pdf

Kuiper, C., Smit, J., De Wachter, L., \& Elen, J. (2017). Scaffolding tertiary students' writing in a genre-based writing intervention. Journal of Writing Research, 9(1), 27-59. https://doi.org/10.17239 jowr-2017.09.01.02

Kusumaningrum, W. R. (2015). Genre-based approach to promote learners' critical thinking skills. Transformatika: Jurnal Bahasa, Sastra, Dan Pengajarannya, 11(2), 96-107. https://doi.org/10.31002/transformatika.v11i2.216

Liu, J. Y. (2018). Exploring genre pedagogy of learning transfer in L2 writing. The Asian Journal of Applied Linguistics, 5(1), 46-59. Retrieved from https://caes.hku.hk/ajal/index.php/ajal/article/view $/ 518$

Maguire, M., \& Delahunt, B. (2017). Doing a thematic analysis: A practical, stepby-step guide for learning and teaching scholars. All Ireland Journal of Higher Education, 9(3), 3351-33514. Retrieved from https: //ojs.aishe.org/index.php/aishe-j/article/view 3350

Martin, J. R. (2014). Evolving systemic functional linguistics: Beyond the clause. Functional Linguist, 1,3. https://doi.org/10.1186/2196-419X-1-3

Martin, J. R., \& Rose, D. (2005). Designing literacy pedagogy: Scaffolding democracy in the classroom. In J. Webster, C. Matthiessen, \& R. Hasan (Eds.), Continuing discourse on language: A functional perspective (Vol. 1) (pp. 251-280). London: Continuum. Retrieved from http://aall.org.au/sites/default/files/DesignLiteracyPedagogy.pdf

McGuinness, C., \& Fulton, C. (2019). Digital literacy in higher education: A case study of student engagement with e-tutorials using blended learning. Journal of Information Technology Education: Innovations in Practice, 18, 128. https: //doi.org/10.28945/4190 
Ministry of Education and Culture of the Republic of Indonesia. (2018). Materi penyegaran instruktur kurikulum 2013 SMP tahun 2018 [Material for instructor refreshing of the 2013 junior high school curriculum in 2018]. Jakarta.

Morley, G. D. (2000). Syntax in functional grammar: An introduction to lexicogrammar in systemic linguistics. London: Continuum.

Nagao, A. (2019). The SFL genre-based approach to writing in EFL contexts. Asian-Pacific Journal of Second and Foreign Language Education, 4(1), 6. https://doi.org/10.1186/s40862-019-0069-3

Nahid, A., Suseno, M., Pujiati, H., \& Juanda, J. (2018). Genre-based approach to teaching speaking of descriptive text (A case study at a rural junior high school in South West Nusa, Indonesia). Pedagogy: Journal of English Language Teaching, 6(1), 65-76. https://doi.org/10.32332/pedagogy.v6i1.1129

Negretti, R., \& McGrath, L. (2018). Scaffolding genre knowledge and metacognition: Insights from an L2 doctoral research writing course. Journal of Second Language Writing, 40, 12-31. https://doi.org/10.1016/j.jslw.2017.12.002

Nugraha, D. S. (2013). Helping students understand the text through scaffolding. Journal on English as a Foreign Language, 3(2), 53-58. https://doi.org/10.23971 ßjefl.v3i2.63

Nurvitasari, D. S. R., Wardhana, P. A., \& Arini, Y. D. (2019). Bahasa Inggris SMP/MTs kelas VIII semester 1. Yogyakarta: Intan Pariwara.

Oliveira, L. C. D. (2015). A Systemic-functional analysis of English language learners' writing. DELTA: Documentação de Estudos Em Lingüística Teórica e Aplicada, 31(1), 207-237. https://doi.org/10.1590/01024450364601799092306

Palinkas, L. A., Horwitz, S. M., Green, C. A., Wisdom, J. P., Duan, N., \& Hoagwood, K. (2015). Purposeful sampling for qualitative data collection and analysis in mixed method implementation research. Administration and Policy in Mental Health and Mental Health Services Research, 42(5), 533544. https://doi.org/10.1007/s10488-013-0528-y

Rohmann, H. (2015). Free image on Pixabay-children, school children, boy. München: Pixabay. Retrieved from https://pixabay.com/1llustrations/children-school-children-boy-girl$965506 /$

Rose, D. (2005). Democratising the classroom: A literacy pedagogy for the new generation. Journal of Education, 37(1), 131-168. Retrieved from https:/hdl.handle.net/10520/AJA0259479X_158 
Sabouri, H., Zohrabi, M., \& Vafa, A. (2014). Genre-based approach to teaching writing in EFL context. International Journal of Applied Linguistic Studies, 3(1), 01-07. Retrieved from http://ijals.science-line.com/index.php/vol-3no-1-mar-2014

Schall-Leckrone, L. (2017). Genre pedagogy: A framework to prepare History teachers to teach language. TESOL Quarterly, 51(2), 358-382. https://doi.org/10.1002 tesq.322

Smit, J., Bakker, A., van Eerde, D., \& Kuijpers, M. (2016). Using genre pedagogy to promote student proficiency in the language required for interpreting line graphs. Mathematics Education Research Journal, 28(3), 457-478. https://doi.org/10.1007/s13394-016-0174-2

Thomas, D. (2006). A general inductive approach for analyzing qualitative evaluation data. American Journal of Evaluation, 27(2), 237-246. https://doi.org/10.1177/1098214005283748

Vygotsky, L. S. (1978). Mind in society: The development of higher psychological processes (M. Cole, Ed.). Cambridge: Harvard University Press.

Wachidah, S., Gunawan, A., Diyantari, \& Khatimah, Y. R. (2017a). Buku bahasa Inggris: "When English Rings a bell" (2 ${ }^{\text {nd }}$ ed.). Jakarta: Pusat Kurikulum dan Perbukuan, Balitbang, Kemendikbud.

Wachidah, S., Gunawan, A., Diyantari, \& Khatimah, Y. R. (2017b). Buku guru bahasa Inggris: "When English Rings a bell" (2 ${ }^{\text {nd }}$ ed.). Jakarta: Pusat Kurikulum dan Perbukuan, Balitbang, Kemendikbud.

Whittaker, R. (2018). Reading to Learn in CLIL Subjects: Working with contentlanguage. CLIL. Journal of Innovation and Research in Plurilingual and Pluricultural Education, 1(1), 19-27. https: //doi.org/10.5565/rev/clil.4

Zurdianto, Z. (2016). Genre based approach to teaching narrative writing. AlTsaqafa: Jurnal Ilmiah Peradaban Islam, 13(01), 99-114. https://doi.org/10.15575/al-tsaqafa.v13i01.1834

\section{Authors' Brief CV}

Aunurrahman is a lecturer of the English Education Department of IKIP-PGRI Pontianak. He has vast interests in English language teaching, linguistics, and individual differences. He welcomes researchers around the world to collaborate in research and writing for publications. He could be reached by email: yarrha@gmail.com 
Any Hikmayanti is a teacher at MTs Negeri 2 Pontianak. She has taught English subject for more than 10 years. Her knowledge and experiences in English language teaching have brought her to become a professional and great teacher. She could be reached by email: anyhikmayanticantik@gmail.com

Yuliana is the principal of MTs Negeri 2 Pontianak. She has dedicated herself as a principal who manages the administrations and teaching qualities. She could be reached by email: yuliana.arsyad2019@gmail.com 